\title{
UNIFICATION OF THE ANALOG PART OF THE BIOSIGNAL PROCESSING CHANNEL
}

\author{
Volodymyr Khoma ${ }^{1}$; Yuriy Khoma ${ }^{1}$; Orest Kochan ${ }^{1,2}$ \\ ${ }^{1}$ Lviv Polytechnic National University, Lviv, Ukraine \\ ${ }^{2}$ School of Computer Science, Hubei University of Technology, Wuhan, China
}

\begin{abstract}
Summary. Measurement methods and design principles for measuring channel are considered in this paper. They extend the capacity of improving noise immunity and resolution of bio-signals measurement means. The analog parts of measuring channels for measurement of different kinds of bio-signals, as well as the sources of errors for such channels are analyzed. The structure of the analog part of the high-precision universal measuring channel (invariant to the type of the measured bio-signal) is developed on the basis of this analysis.
\end{abstract}

Key words: bio-signal, bio-impedance, sensor fusion, measuring channel, distortion resistance.

https://doi.org/10.33108/visnyk_tntu2020.01.097

Received 19.03.2020

Statement of the problem. Bio-signals measuring and processing is significantly different from the similar tasks that arise in various fields of science and technology. This is caused primarily by the of biological processes peculiarity that occurs in living organisms. Traditionally, bio-signals are used as valuable information carriers in medical diagnostics. However, interest in bio-signals is extended to other areas that demand new requirements regarding technical and operational characteristics of biomedical indices selection, measurement, processing and interpretation.

Analysis of available studies results. Bio-signals are the reflections of psychophysiological processes occurring in living organism, hence it is possible to determine biomedical indices by bio-signals measuring and processing, which are important not only in the field of medicine, but in such new fields of bioinformatics as biometrics, affective informatics or neural network interfaces as well [1-4]. At present, bio-signals computing is widely used, and is connected, on the one hand, with the implementation of a number of typical transformations, such as bio-signal generation and selection, amplification, silencing, artifacts influence reduction, emissions elimination, normalization, segmentation, informative features highlighting, results classification and interpretation [5-7]. Similar transformations, on the other hand, can be performed due to both specialized analog devices and more versatile digital ones. Therefore, in order to achieve greater unification and flexibility of the measuring channel (MC), the immediate task is to investigate the broadest possible digital bio-signals transformation. However, since the part of measurement transformations, for various reasons, is to be implemented in the analog part of MC, it is important to investigate the possibilities of its maximum unification.

At present dozens of bio-signals having different origins and method of formation are used in biomedical studies [8]. The combination of different methods can be used to increase the validity of the results during the study. Such an approach in modern bioinformatics is called sensor fusion. The example of practical sensor fusion application is polygraph (lie detector). In order to improve the test results, multichannel measurements of various physiological 
characteristics related to human psycho-emotional responses to the asked questions are used [9].

The objective of the paper is to investigate the ways of measurement unification of bio-signals transformations with different nature and to develop the structure of the analog part of the computer measurement system, suitable for solving a wide range of modern bioinformatics problems.

Statement of the problem. In order to achieve this target, it is necessary to consider the varieties of bio-signals, mechanisms of their formation, to analyze the factors complicating the bio-signals selection, and to describe the peculiarities of measurement transformations on the examples of electrocardiogram signal and bio-impedance. This will serve as a basis for the rational use for measurement transformations of the modern component base capabilities providing the possibility of compatible processing for various kinds of bio-signals, as well as invariance of the destabilizing factors action.

Types and parameters of the most common bio-signals. By the method of formation the bio-signals can be ranged to one of the following three groups [5], as shown in table 1:

I. Bio-signals of electrical nature.

II. Bio-signals reflecting non-electrical processes.

III. Bio-signals as the response to external stimuli.

Table 1

The most common biosignals and their main parameters

\begin{tabular}{|c|c|c|c|c|}
\hline $\begin{array}{c}\text { Signal } \\
\text { type }\end{array}$ & $\begin{array}{c}\text { Classification } \\
\text { Group }\end{array}$ & $\begin{array}{c}\text { Frequency } \\
\text { interval, } \mathbf{H z}\end{array}$ & $\begin{array}{c}\text { Intensity } \\
\text { range }\end{array}$ & Change pattern \\
\hline ECG & I & $0,01-250$ & $1-5 \mathrm{mV}$ & Quasi-periodic \\
\hline EEG & I & $0-150$ & $5-300 \mu \mathrm{V}$ & Transient \\
\hline EMG & I & $0-10000$ & $0,1-5 \mathrm{mV}$ & Transient \\
\hline EDR & I & $0,1-10$ & $0,1-2 \mathrm{mV}$ & Transient \\
\hline VAG & II & $80-800$ & $10 \mathrm{mV}$ & Quasi-periodic \\
\hline IPG & III & $0,3-70$ & $1 \mathrm{mV}$ & Harmonic \\
\hline PPG & III & $0,3-70$ & $0,1 \mathrm{mV} \mathrm{order}$ & Quasi-periodic \\
\hline BIA & III & $0,1-10$ & $0,1-2 \mathrm{mV}$ & Harmonic \\
\hline
\end{tabular}

The first group combines methods when bio-signal is formed as the difference of electrical potentials on the body surface by means of special electrodes located at certain points. Such bio-signals are electrical in nature and can be fed directly to the input of a computer measurement system without additional transformations. According to this principle, biosignals that belong to such electro-diagnosis methods as electrocardiography (ECG), electroencephalography (EEG), electromyography (EMG), electrococulography (EOG), electrogastrography (EGG), and others are recorded.

The second group consists of diagnostic methods where bio-signal is generated by special primary transducers (sensors) and reflects the physiological processes of non-electrical nature occurring in the body. These include vibroarthrography (VAG), plethysmography (IPG), 
sphygmography (SG) and a number of other methods. The third group of methods for biosignals generation requires the application of external physical fields (electrical, optical, etc.) to the biological material. This group is represented by methods such as impedance magnetic resonance imaging (MRI), plethysmography (IPG), photoplethysmography (PPG), bioimpedance analysis (BIA), electrodermal response (EDR).

From the point of view of bio-signals measurement and processing, their parameters such as frequency interval, levels range, the nature of changes over time are important. Parameters of the most common bio-signals are provided in Table 1. Bio-signals, which according to the proposed classification belong to the first group, are electrical in nature, hence they can be directly recorded by the electrodes as the potential difference on the body surface. These signals are weak, especially EEG, and therefore they are sensitive to interferences and have low Signal to Noise Ratio (SNR) [10].

Peculiarities of electric bio-potentials selection. Electrocardiography, electroencephalography, and electromyography systems are designed to study of heart, brain, and muscle activity, respectively, by measuring electrical potentials on the body surface. Nervous irritations and muscle contractions can be detected by measuring the ion current flow in living tissues. This is performed by bio-potential electrodes.

The selection of bio-potentials from the body surface has the following peculiarities [11]:

- in biological organisms, unlike electrical devices, charge carriers are not electrons but ions in the cell electrolyte (positively charged cations and negatively charged anions), so the bio-potential at a certain area of the body surface occurs due to excessive concentration of ions of a certain type;

- while the bio-potential electrodes are attached, such exceptionally undesirable phenomenon as polarization occurs, the potential of which can exceed the useful signal by two orders;

- the impedance between the skin and the electrode is resistive-capacitive, and its value at $10 \mathrm{~Hz}$ frequency can range from $5 \mathrm{kOhm}$ to $500 \mathrm{kOhm}$;

- biosignals, generated as bio-potentials difference of between various parts of the body surface, have very low levels and therefore are sensitive to interferences of different origins.

Equivalent electrical reflecting processes at the «skin-biopotential electrode» contact during ECG signal recording process is shown in Figure 1, a.

The polarization phenomenon, which in the substitution diagram reflects the voltage source $\mathrm{E}_{\mathrm{HC}}$, the impedance of the «skin-electrode» contact represented by parallel $\mathrm{R}_{\mathrm{E}} \mathrm{C}_{\mathrm{E}}$ circuit, as well as subdermal tissues resistance $\mathrm{R}_{\mathrm{U}}$, are destabilizing factors complicating bio-signals selection. ECG signal is recorded by means of electrodes as electrical potentials difference $\Delta U$ at different parts of the body surface. The values of the equivalent circuit parameters for each electrode are usually different, i. e. there is asymmetry. The effect of the useful signal on polarization voltage is additive, and the change of the «skin-electrode» contact impedance is multiplicative.

If the electrode moves because of breathing or movement, it disrupts the charge distribution at the edge of its contact with the cell electrolyte and changes the polarization potential. This phenomenon is called the movement artifact, which can be a serious reason for the decrease of the electrocardiogram measurement accuracy (or any other bio-signal).

The following is used in clinical practice in order to ensure the maximum quality of the recorded ECG signal [12, 13]:

- gel for increasing the conductivity of «body-electrode» contact;

- comfortable conditions for the examined person (comfortable resting on the couch);

- $\quad$ breath holding arrest at the moment of ECG recording; 
- multichannel bio-potentials recording from the limbs and different points of chest and limbs (up to 12 extensions).

Recently, ECG has been used not only for medical examinations but also for other purposes, for example, people identification $[14,15]$. The biometrics aims are different from medical diagnostic ones, but the conditions for ECG selection are also different. In biometric tasks, the main aim is to record the signal from human being from the so-called first extension using dry electrodes from the fingers of the left and right hands as easily as possible. It is also possible to get ECG signal from the chest using T-shirt with built-in textile electronics, from office or driver chair or even wrist bracelet $[16,17]$. Such non-conventional but convenient ECG signals selection methods are becoming available for regular use and the spheres of their potential application are expanding.

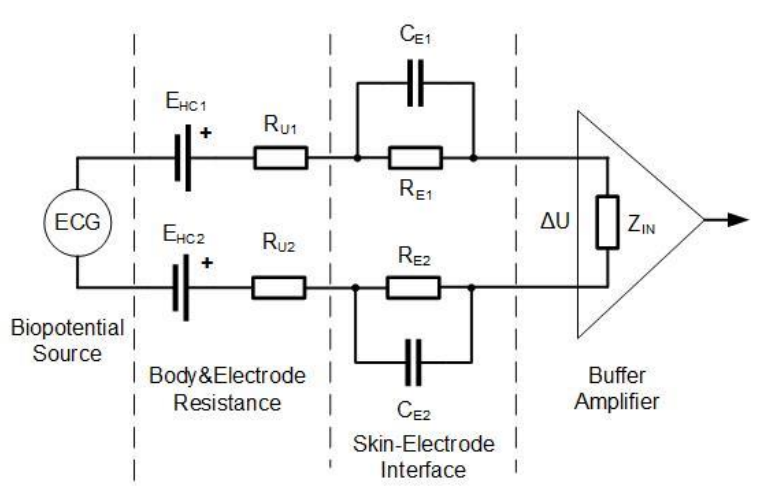

a)

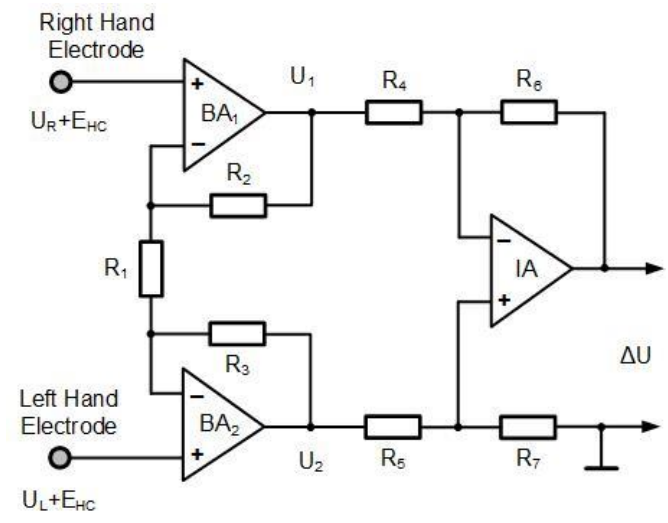

b)

Figure 1. Equivalent circuit diagram of bio-potential electrodes substitution(a) and input stage circuit at ECG registration from the first extension (b)

Simple bio-potential selection procedure, dry electrodes cannot provide good quality of the recorded ECG signal. Buffer amplifier (BA) with large $Z_{I N}$ input impedance (Figure 1) should be used to ensure invariance of the impedance effect. Buffer amplifiers are required to have ultra-low input current displacements values (several pA) in order to prevent additional polarization of the «skin-electrode» contact, especially if this contact is degraded. The availability of buffer amplifiers makes it possible to use the so-called dry electrodes [17], i. e, those that do not need gel to improve the «skin-electrode» contact. The combination of biopotential electrode with buffer amplifier is called «active electrode».

Measuring transformations on the example of ECG signal and implementation variations of MC analog part. The electrocardiogram signal excursion ranges from $\Delta U=1 \div 5$ $\mathrm{mV}$, and polarization voltage for popular biopotential $\mathrm{Ag} / \mathrm{AgCl}$ electrodes can even assume the value $E_{H C}=300 \mathrm{mV}$, i. e. the value by two orders greater than the useful signal. In addition, the polarization voltage is unstable as in the process of bio-potentials recording it changes its value, making it difficult to compensate its influence.

The application of instrumentation amplifier (IA) with high coefficient (100 Db) of Common-Mode Rejection Ratio (CMRR) reduces the destructive effect of polarization potentials $[18,19]$. For the buffer cascade (Fig. 1b) in the first approximation it is true that

$$
I=\left(U_{1}-U_{R}\right) / R_{2}=\left(U_{2}-U_{L}\right) / R_{2}=\left(U_{R}-U_{L}\right) / R_{1}
$$


as well as

$$
U_{1-} U_{2}=\left(U_{R^{-}} U_{L}\right)\left(1+R_{2} / R_{1}\right) \text {. }
$$

If $U_{R}=U_{L}=E_{C M}$, then $U_{l}=U_{2}=E_{C M}$, and

$$
C M R R=A_{D 1} \times A_{D 2} / A_{C M 1} \times A_{C M 2}
$$

where $A_{D 1}$ and $A_{D 2}$ are differential signal enhancement ratios for buffer amplifiers $\mathrm{BA}_{1}$ i $\mathrm{BA}_{2}$; $A_{C M 1}$ and $A_{C M 2}$ are Common-Mode Rejection Ratios $\mathrm{BA}_{1}$ and $\mathrm{BA}_{2}$.

In order to compensate the polarization voltage, the principle of negative feedback is traditionally used. This is achieved by the formation and supply to the electrode of the right leg of the corresponding potential (Figure 2, a). The common-mode voltage on the body is measured by two resistors with values of $\mathrm{R}_{1} / 2$ and due to the inverting amplifier based on OA and $\mathrm{R}_{3}$ resistor is returned to the right leg in the form of current less than $1 \mu \mathrm{A}$. This makes it possible to grade the bias voltages flowing in the body, which can be considered as the adder of currents in the feedback loop. Thus, the negative feedback of the circuit on the operational amplifier reduces the level of common-mode voltage at the measuring electrodes.

If there is asymmetry in the impedance of the «electrodes-skin» contact, the commonmode potential of the body will be different at the inputs of the first and second buffer amplifiers. Therefore, the residual part of common-mode will be considered as differential voltage and will be amplified by instrumentation amplifier. In the registered ECG signal, this distortion is called the baseline drift with spectrum having the band from 0.5 to $1 \mathrm{~Hz}$. The analog high-pass filter is often used to this distortion rejection, particularly within the instrumentation amplifier.

Except the above mentioned addition, there is a number of other sources of ECG signal distortions, mainly of adaptive character including: power supply induction $(50 \mathrm{~Hz})$, muscle electrical activity interference $(5 \mathrm{~Hz}-2 \mathrm{kHz})$, and electromagnetic interferences.

The spectrum of ECG signal itself extends over the band from 0.01 to $250 \mathrm{~Hz}$, although it is believed that the main informative components are concentrated mostly within the range of $0.25-35 \mathrm{~Hz}$ [13]. At the present, it is reasonable to use digital signal processing (DSP) techniques to reduce the interference impact, i. e. to increase the signal-to-noise ratio. This requires analog-to-digital signal conversion. Proper implementation of analog-to-digital conversion requires matching of the signal level with the dynamic ADC range, and selecting the sampling rate $T_{S}{ }^{-1}$, taking into account the upper band $F_{M A X}$ of the converted signals $-T_{S}{ }^{-1} \geq$ $2 F_{M A X}$. 


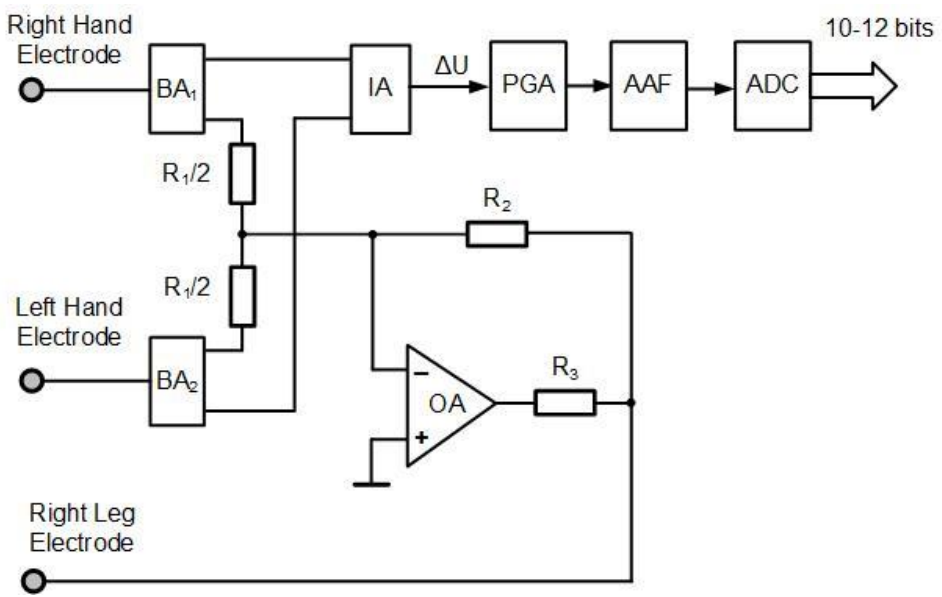

a)

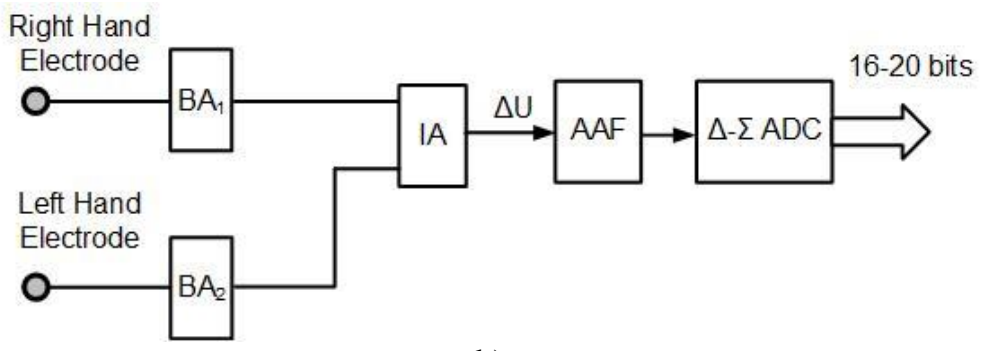

b)

Figure 2. The structure of the analog part of measurement circuit for electrocardiogram selection from the first extension: typical (a) and based on high width ADC (b)

In order to limit the raw ECG signal spectrum from the top, the low-pass anti-aliasing filter (AAF) with $250 \mathrm{~Hz}$ transition band is applied, then the sampling rate should be at least $500 \mathrm{~Hz}$. Program-guided gain factor amplifier (PGA) is used to match the raw signal level to the Dynamic Analog-to-Digital Converter (ADC) range. A typical structure of the analog part of measuring circuit for electrocardiogram selection is shown in Figure 2 a.

ECG-channel consists of measuring biopotential electrodes $E_{1}$ and $E_{2}$, connected relatively to buffer amplifiers $\mathrm{BA}_{1}$ and $\mathrm{BA}_{2}$, instrumentation amplifier IA with program-guided gain factor, anti-aliasing filter $\mathrm{AAF}, \mathrm{ADC}$ and bias compensator on the basis of operational amplifier (OA). In most cases, electrocardiogram single-channel selection is performed by connecting one electrode to the right arm, the other to the left one, and the bias electrode to the right leg. However, simplified and more convenient methods of electrode positioning are possible, for example, the first electrode to the index finger of the right hand, the second to the index finger of the left hand, and the bias electrode to the long finger of the left hand.

Such structure of ECG-signal selection channel can be implemented as a separate module for mobile applications [20]. To perform more complex tasks involving electrocardiograms selection from many extensions or integration with other types of biosignals, the measuring circuit can be implemented on the basis of delta sigma ADC ( $\Delta$-ADC) with resolution 16-20 bits (Figure $2 \mathrm{~b}$ ). This ensures useful information storage from weak ECG signal on the background of uncompensated polarization voltage, influence rejection of which takes place in MC digital part.

Bio-signals measuring circuits included in groups I and II can be combined. The only difference is in the input device (electrodes or sensors). The third group of bio-signals, 
particularly bio-impedance, is formed by means of external stimuli, thus the structure of measuring circuit is fundamentally different and usually more complicated.

Bio-impedance and measuring channel construction options. Living biological tissue is inhomogeneous conductor with resistive-capacitive impedance character which individual elements reflect the external and internal cells resistance and cell membrane capacity. For different types of tissues and cells of the body, the values of these components significantly differ being the basis for obtaining valuable biomedical information.

There are many different problems in bioinformatics solved by bio-impedance measurement. The most common problems include body impedance analysis, impedance plethysmography, and electrodermal activity. In each of these tasks, bio-impedance measurement has its own peculiarities. For example, measuring body composition involves recording the frequency dependence of active and reactive bio-impedance components, impedance plethysmography (rheography) is associated with the registration of minor bioimpedance temporal pulses caused by blood filling of the investigated organs, and dermal impedance changes caused by human emotional response on asked questions are used as one of the polygraph information channels [9].

Since bio-impedance is passive a value, it is converted for measurement purposes into active value, usually voltage. This is due to the bio-impedance sensing by external stimuli, for example, in the form of harmonic current. In general, the principle of such transformation is shown in the scheme in Figure 3, a.

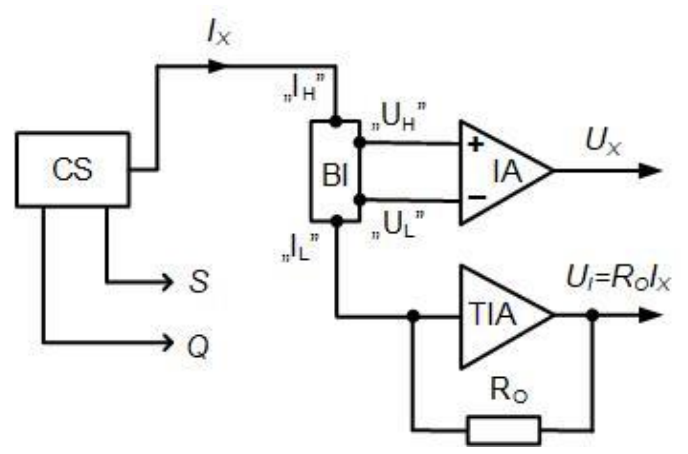

a)

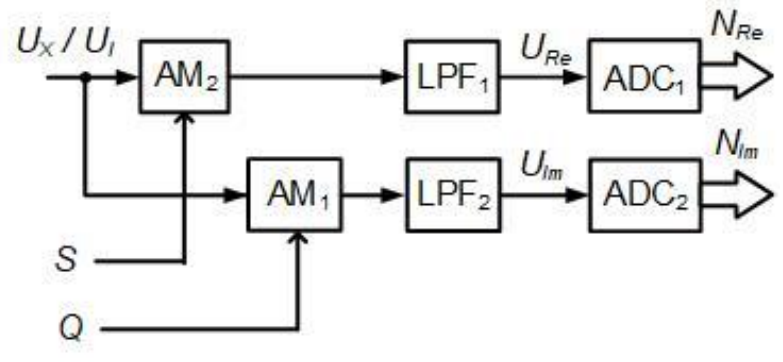

b)

Figure 3. Converter of bio-impedance into voltage (a) and phase-quadrature converter (b)

Four electrodes - two current ( $\left\langle\mathrm{I}_{\mathrm{H}}\right\rangle,\left\langle\mathrm{I}_{\mathrm{L}} \gg\right)$ and two potential $\left(« \mathrm{U}_{\mathrm{H}}\right\rangle,\left\langle\mathrm{U}_{\mathrm{L}} »\right)$ are put on the investigated body area. Current electrodes are connected to current source (CS), and potential ones - to the high-resistance inputs of the instrumentation amplifier (IA). Since the voltage decline $U_{X}$ on the body area is registered on the instrumentation amplifier, then under Ohm's law it is possible to determine the value of bioimpedance (BI)

$$
Z_{X}=U_{X} / I_{X}
$$

Transimpedance amplifier (TIA) with transmission ratio $1 / R_{O}$ is used for current measurement, so the equation for bio-impedance conversion is as follows

$$
Z_{X}=R_{O} \times U_{X} / I_{X} Z_{X}
$$

where $R_{O}$ and $U_{I}$ are the resistor resistance of the trans-impedance amplifier and its output voltage, respectively. 
The next key stage in measurement transformation is separation of the common-mode and quadrature components of $U_{X}$ and $U_{I}$ signals of the "bio-impedance-voltage" converter. Traditionally (see Figure 3, b), the phase-quadrature decomposition of complexes is based on the In Lock Amplifiers [21, 22].

In Lock Amplifier is constructed on the basis of analog multiplier (AM) multiplying analyzed complex voltage $\left(U_{X}\right.$ or $\left.U_{I}\right)$ by reference signal. Since the reference signals $S$ and $Q$ are in quadrature, the constant components of $U_{\mathrm{Re}}$ and $U_{\mathrm{Im}}$ signals at $\mathrm{AM}_{1}$ and $\mathrm{AM}_{2}$ output are proportional to the real and imaginary components of the complex voltage. The separation of the constant components is carried out by means of $\mathrm{LPF}_{1}$ and $\mathrm{LPF}_{2}$ low-pass filters, and their conversion to digital form - by $\mathrm{ADC}_{1}$ and $\mathrm{ADC}_{2}$ analog-to-digital converters.

The values of module, phase, active and reactive bio-impedance components are calculated in the digital unit of measuring channel by the following expressions:

$$
\begin{gathered}
M_{\mathrm{Re}}=\frac{1}{N} \sum_{n=0}^{N-1} U_{X}(n) \times S(n)=\frac{A}{2} \cos (\varphi) ; \quad M_{\mathrm{Im}}=\frac{1}{N} \sum_{n=0}^{N-1} U_{X}(n) \times Q(n)=\frac{A}{2} \sin (\varphi) ; \\
M_{A}=2 \sqrt{M_{\mathrm{Re}}^{2}+M_{\mathrm{Im}}^{2}} ; \quad M_{\Phi}=\arctan \left(\frac{M_{\mathrm{Im}}}{M_{\mathrm{Re}}}\right)
\end{gathered}
$$

There is another option of bio-impedance measuring channel construction, which peculiarity is to perform phase-quadrature conversion in a digital form. For this purpose, the instantaneous magnitudes of the complex voltages $U_{X}$ and $U_{I}$ at the output of the «bioimpedance-voltage» converter are digitized. The sampling rate is related to the probe current frequency

$$
T_{S}^{-1}=N \times F_{O},
$$

where $N$ is the number of samples.

It should be noted that instrumentation amplifier and ADC require increased operation speed. If, in the case of measuring biosignals from groups I and II, the spectrum is limited to several hundred $\mathrm{Hz}$, then for the measurement of bioimpedance at $50 \mathrm{kHz}$ probe signal frequency, the sampling rate is hundreds of $\mathrm{kHz}$, i. e. approximately three orders higher.

Unified channel structure for measuring different types of biosignals. On the basis of the above mentioned, we can assume that the use of multi-bit (16-20 bits) [23] and highspeed (about $10^{6}$ samples per second) analog-to-digital converters is the key to the construction of a unified analog measurement circuit part, providing measurement of a wide range of biosignals. The structure of the bioinformatics computer system for processing bio-signals with the unified analog measuring channel part is shown in Figure 4.

Electrical bio-potentials selection (biosignals of group I) is performed using active electrodes (AEs) and are fed to the analog multiplexer (AMX) that provides multi-channel measurements, such as 12 extensions in electrocardiography or 32 electrodes for encephalographic studies. Bioprocesses of non-electrical nature (bio-signals of group II) are converted into electrical signals by appropriate bio-signal sensors (SB) sensors to ensure their compatibility with the system. Bio-impedance representing bio-signals of group III, requires external stimuli for converting into electrical voltage in $\mathrm{Z} / \mathrm{U}$ Converter. Their formation involves digital voltage synthesizer (DVS) and «voltage-to-current» converter (U/I Converter). The latter can be implemented according to Hawland current generator scheme [24], and DVS on the basis of digital direct synthesis (DDS) [25]. 


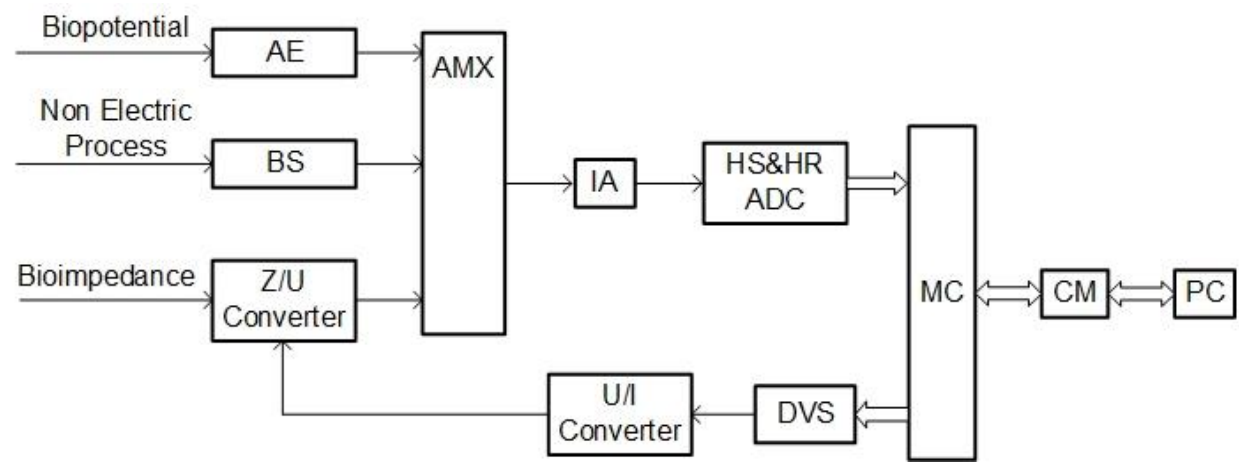

Figure 4. Structure of bioinformatics computational system for bio-signal processing

The signals from the analog multiplexer are conditioned in the instrumentation amplifier and fed to multi-bit high-speed analog-to-digital converter (HS\&HR ADC). Further the digitized data are fed to microcontroller (MC), which implements various digital signal processing algorithms aimed at rejection of interferences from power network, electromagnetic noise and biological interference (tremors, electrical muscle activity, isoline drift). A number of functional transformations, such as single-frequency Fourier transformation, bio-impedance parameters calculation, etc. are performed in MC. The microcontroller is connected to PC via switch module $(\mathrm{CM})$, where various application algorithms, including machine learning technologies are implemented [12].

A common feature of all types of biosignals is their weakness. Moreover, there is a number of destabilizing factors having pure physiological origin. They can be conditionally divided into three types - interference, shielding, variability of the controlled parameter [5]. As a result, there is a low signal-to-noise ratio. Based on the own research data and literature sources, the main biosignals distortions and ways of their reasonable reduction are presented in Table 2.

Table 2

Main biosignals distortions and methods of their reduction

\begin{tabular}{|c|c|l|}
\hline Distortion source & $\begin{array}{c}\text { Character of distortion } \\
\text { and its spectrum }\end{array}$ & $\begin{array}{c}\text { Methods and means of interferences } \\
\text { and artifacts rejection }\end{array}$ \\
\hline $\begin{array}{c}\text { «Skin-electrode» } \\
\text { impedance }\end{array}$ & $\begin{array}{c}\text { Multiplicative, } \\
5-500 \mathrm{kOhm}\end{array}$ & $\begin{array}{l}\text { Buffer amplifier, active electrode (high } \\
\text { input resistance, low bias currents) }\end{array}$ \\
\hline $\begin{array}{c}\text { Bias currents, } \\
\text { polarization } \\
\text { voltage }\end{array}$ & $\begin{array}{c}\text { Additive, } \\
0-0,01 \mathrm{~Hz}\end{array}$ & $\begin{array}{l}\text { Instrumentation amplifier (high common- } \\
\text { mode rejection ratio), } \\
\text { Delta-sigma ADC (high width) }\end{array}$ \\
\hline Isoline drift & $\begin{array}{c}\text { Additive, } \\
\text { frequency band }<0,1 \mathrm{~Hz}\end{array}$ & $\begin{array}{l}\text { Digital high pass filter, } \\
\text { Wave decomposition }\end{array}$ \\
\hline $\begin{array}{c}\text { Power supply } \\
\text { guidance }\end{array}$ & $\begin{array}{c}\text { Additive, } \\
\text { frequency } 50 / 60 \mathrm{~Hz}\end{array}$ & Digital notch filter \\
\hline $\begin{array}{c}\text { Electromagnetic } \\
\text { noise }\end{array}$ & $\begin{array}{c}\text { Additive, } \\
\text { wide frequency band }\end{array}$ & $\begin{array}{l}\text { Digital low pass filters with linear phase } \\
\text { response }\end{array}$ \\
\hline
\end{tabular}


It is evident from the data given in Table 2, that the influence of artifacts and interferences on bio-signals at present can be reduced by digital means.

Conclusions. Bio-signals measurement and processing are related not only to medical diagnostics, but to many new applications in bioinformatics, such as biometrics, humanmachine interaction, round-the-clock clinical monitoring as well. New applications increase the requirements for both technical and operational performance of bio-signals selection and conversion means. Particularly, it is necessary to select bio-signals outside the stationary conditions using wearable means, to ensure simultaneous processing of different types of biosignals in order to improve the results validity. In this context, it is necessary to unify the bioinformatics system hardware, especially its analog part.

The properties of bio-signals having electrical nature from the point of view of their measurement are analyzed and the most common problems and errors during their measurement are considered in this paper. At the same time, typical analog parts of bio-potentials and bioimpedance measurement channels, as well as methods of the measured signals processing to improve the measurements accuracy are considered as well. On the basis of the carried out analysis, the common properties of these bio-signals were identified. This made it possible to synthesize the structure of the analog part of high-precision measuring channel of bio-signal processing invariant to the type of measured bio-signal, which can apply the well-known methods of signal processing (analog and digital filtering, signal decomposition, multi bit ADC application) for measurement accuracy improvement.

\section{References}

1. Rangayyan R. Biomedical Signal Analysis. A Case-Study Approach. John Willey and Sons Inc. 2015. 552 p. DOI:10.1002/9781119068129. https://doi.org/10.1002/9781119068129

2. Dozorska $\mathrm{O}$. The mathematical model of electroencephalographic and electromyographic signals for the task of human communicative function restoration. Scientific Journal of TNTU. 2018. Vol. 92. No 4. P. 126-132. https://doi.org/10.33108/visnyk_tntu2018.04.126

3. Zhevandrova YA., Syropyatov A., Buryak V. Kompleksnaya byometrycheskaya autentyfykatsyya lychnosty. Systemy obrobky informatsiyi. 2016. Vol. 141. Issue 4. P. 104-107. [In Russian]. https://doi.org/10.1111/cas.12776

4. Niedenthal P. M., Halberstadt J. B., Margolin J., Innes-Ker A. H. Emotional state and the detection of change in facial expression of emotion in European Journal of Social Psychology. Vol. 2000. No. 30. P. 211-222. URL: https://doi.org/10.1002/(SICI)1099-0992(200003/04)30:2<211::AID-EJSP988>3.0. $\mathrm{CO} ; 2-3$.

5. Khoma Y. V., Stadnyk B. I., Mykyychuk M. M., Frish S. Metody i zasoby vymiryuvannya ta kompyuternoho opratsyuvannya biosyhnaliv. Vymiryuval'na tekhnika ta metrolohiya. 2018. Vol. 79. Issue 3. P. 5-16. URL: https://doi.org/10.23939/istcmtm2018.03.005. [In Ukranian].

6. Pelc M., Khoma Y., Khoma V. ECG Signal as Robust and Reliable Biometric Marker: Datasets and Algorithms Comparison in Sensors. 2019. Vol. 19. No. 10.2350. P. 1-8. https://doi.org/10.3390/s19102350.

7. Sverstiuk A. Comparative analysis of results of numerical simulation of cyber-physical biosensor systems on the basis of lattice differential equations. Scientific Journal of TNTU. 2019. Vol 95. No. 3. P. 123-138. https://doi.org/10.33108/visnyk_tntu2019.03.123

8. Abakumov V. H., Hotra Z. Y., Zlepko S. M., et all. Reyestratsiya, obrobka ta kontrol' biomedychnykh syhnaliv. Vinnytsya: VNTU, 2011.352 p. [In Ukranian].

9. Ogloblin S., Molchanov A. Instrumental'naya "detektsiya lzhi". Yaroslavl': Nyuans, 2004. 411 p. [In Russian].

10. Jun S., Kochan O. Common mode noise rejection in measuring channels. In Instruments and Experimental Techniques. 2015. Vol. 58. No. 1. P. 86-89. URL:https://doi.org/10.1134/S00204412150 10091.

11. Valverde E. R., Arini P. D., Bertran G. C., Biagetti M. O., Quinteiro R. A. Effect of electrode impedance in improved buffer amplifier for bioelectric recordings. Journal of Medical Engineering \& Technology. 2004. Vol. 28. Issue 5. P. 217-222. https://doi.org/10.1080/03091900410001662323. 
12. Storchun Y. V. Matviychuk Y. M. Biofizychni ta matematychni osnovy instrumental'nykh metodiv medychnoyi diahnostyky. L'viv: Rastr-7, 2009. 216 p. [In Ukranian].

13. Khoma V., Pelc M., Khoma Y. Artificial Neural Network Capability for Human Being Identification based on ECG Proceedings: the 23rd International Conference on Methods and Models in Automation and Robotics (Miedzyzdroje, 27-30 August 2018.). Miedzyzdroje, 2018. P. 479-482. https://doi.org/ 10.1109/MMAR.2018.8486014

14. Khoma V., Pelc M., Khoma Y., Sabodashko D. Outlier Correction in ECG-Based Human Identification. Biomedical Engineering and Neuroscience. BCI 2018. Advances in Intelligent Systems and Computing. Vol. 720. 2018. P. 11-22. URL: https://doi.org/10.1007/978-3-319-75025-5_2.

15. Fratini A., Sansone M., Bifulco P., Cesarel M. Individual identification via electrocardiogram analysis. BioMed. Eng. OnLine. 2015. Vol. 14. P. 1-23. https://doi.org/10.1186/s12938-015-0072-y.

16. Von Luhmann A., Wabnitz H., Sander T., Muller K.-R. A Mobile, Modular, Multimodal Biosignal Acquisition Architecture for Miniaturized EEG-NIRS-Based Hybrid BCI and Monitoring in IEEE Transactions on biomedical engineering. 2017. Vol. 64. No. 6. P. 1199-1210. https://doi.org/10.1109/ TBME.2016.2594127

17. Aleksandrowicz A., Leonhardt S. Wireless and Non-contact ECG Measurement System - the «Aachen SmartChair» in Acta Polytechnica. 2007. Vol. 47. No. 4-5. P. 68-71.

18. Jun S., Kochan O., Chunzhi W., Kochan R. Theoretical and experimental research of error of method of thermocouple with controlled profile of temperature field. In Measurement Science Review. 2015. Vol. 15. No. 6. P. 304-312. https://doi.org/10.1515/msr-2015-0041.

19. Wang J., Kochan O., Przystupa K., Su J. Information-measuring System to Study the Thermocouple with Controlled Temperature Field. In Measurement Science Review. 2019. Vol. 19. No. 4. P. 161-169. https://doi.org/10.2478/msr-2019-0022.

20. e-Health Sensor Platform V2.0 for Arduino and Raspberry Pi. URL: https://www.cookinghacks.com/documentation/tutorials/ehealth-biometric-sensor-platform-arduino-raspberry-pi-medical (last access: 21.09.19).

21. Orozco L. Synchronous Detectors Facilitate Precision, Low-Level Measurements. Analog Dialogue 48-11, November 2014. URL: https://www.analog.com/media/en/analog-dialogue/volume-48/number4/articles/synchronous-detectors-facilitate-precision.pdf (last access: 29.09.19).

22. He C.,Zhang L., Liu B., Xu Z., Zhang Z., A digital phase-sensitive detector for electrical impedance tomography. In 2008 World Automation Congress. WAC-2008. 28 Sept.-2 Oct. 2008. P. 1-4.

23. Zhengbing H., Kochan R., Kochan O., Jun S., Klym H. Method of integral nonlinearity testing and correction of multi-range ADC by direct measurement of output voltages of multi-resistors divider. In ACTA IMEKO. 2015. Vol. 4. No. 2. P. 80-84. https://doi.org/10.21014/acta_imeko.v4i2.230.

24. AN-1515 A comprehensive study of the howland current pump. Application Report SNOA474A - January 2008-Revised April 2013. P. 1-17.

25. Jian Q., Qun S., Xiaoliang W., Chong W., Linlin C. Design and analysis of a low cost wave generator based on direct digital synthesis. In Journal of Electrical and Computer Engineering. 2015. Vol. 17. P. 1-17. https://doi.org/10.1155/2015/367302

\section{Список використаної літератури}

1. Rangayyan R. Biomedical Signal Analysis. A Case-Study Approach. John Willey and Sons Inc. 2015. 552 p. DOI:10.1002/9781119068129. https://doi.org/10.1002/9781119068129

2. Dozorska $\mathrm{O}$. The mathematical model of electroencephalographic and electromyographic signals for the task of human communicative function restoration. Scientific Journal of TNTU. 2018. Vol. 92. No. 4. P. 126-132. https://doi.org/10.33108/visnyk_tntu2018.04.126

3. Жевандрова Я., Сыропятов А., Буряк В. Комплексная биометрическая аутентификация личности. Системи обробки інформації. 2016. Том. 141. Вип. 4. С. 104-107. https://doi.org/10.1111/cas.12776

4. Niedenthal P. M., Halberstadt J. B., Margolin J., Innes-Ker A. H. Emotional state and the detection of change in facial expression of emotion in European. Journal of Social Psychology. Vol. 2000. No. 30. P. 211-222. URL: https://doi.org/10.1002/(SICI)1099-0992(200003/04)30:2<211::AID-EJSP988>3.0. $\mathrm{CO} ; 2-3$.

5. Хома Ю. В., Стадник Б. І., Микийчук М. М., Фріш С. Методи і засоби вимірювання та комп'ютерного опрацювання біосигналів. Вимірювальна техніка та метрологія. 2018. Том. 79 Вип. 3. С. 5-16. URL: https://doi.org/10.23939/istcmtm2018.03.005.

6. Pelc M., Khoma Y., Khoma V. ECG Signal as Robust and Reliable Biometric Marker: Datasets and Algorithms Comparison in Sensors. 2019. Vol. 19. No. 10. 2350. P. 1-8. https://doi.org/10.3390/s19102350.

7. Sverstiuk A. Comparative analysis of results of numerical simulation of cyber-physical biosensor systems on the basis of lattice differential equations. Scientific Journal of TNTU. 2019. Vol 95. No. 3. P. 123-138. https://doi.org/10.33108/visnyk_tntu2019.03.123 
8. Абакумов В. Г., Готра 3. Ю., Злепко С. М. та ін. Реєстрація, обробка та контроль біомедичних сигналів. Вінниця: ВНТУ, 2011. 352 с.

9. Оглоблин С., Молчанов А. Инструментальная «детекция лжи». Ярославль: Нюанс, 2004, 411 с.

10. Jun S., Kochan O. Common mode noise rejection in measuring channels. In Instruments and Experimental Techniques. 2015. Vol. 58. No. 1. P. 86-89. URL: https://doi.org/10.1134/S002044 1215010091.

11. Valverde E. R., Arini P. D., Bertran G. C., Biagetti M. O., Quinteiro R. A. Effect of electrode impedance in improved buffer amplifier for bioelectric recordings. Journal of Medical Engineering \& Technology. 2004. Vol. 28. Issue 5. P. 217-222. https://doi.org/10.1080/03091900410001662323.

12. Сторчун Є. В. Матвійчук Я. М. Біофізичні та математичні основи інструментальних методів медичної діагностики. Львів: Растр-7, 2009. 216 с.

13. Khoma V., Pelc M., Khoma Y. Artificial Neural Network Capability for Human Being Identification based on ECG Proceedings: the 23rd International Conference on Methods and Models in Automation and Robotics (Miedzyzdroje, 27-30 August 2018.). Miedzyzdroje, 2018. P. 479-482. https://doi.org/ 10.1109/MMAR.2018.8486014

14. Khoma V., Pelc M., Khoma Y., Sabodashko D. Outlier Correction in ECG-Based Human Identification. Biomedical Engineering and Neuroscience. BCI 2018. Advances in Intelligent Systems and Computing. Vol. 720. 2018. P. 11-22. URL: https://doi.org/10.1007/978-3-319-75025-5_2.

15. Fratini A., Sansone M., Bifulco P., Cesarel M. Individual identification via electrocardiogram analysis. BioMed. Eng. OnLine. 2015. Vol. 14. P. 1-23. https://doi.org/10.1186/s12938-015-0072-y.

16. Von Luhmann A., Wabnitz H., Sander T., Muller K.-R. A Mobile, Modular, Multimodal Biosignal Acquisition Architecture for Miniaturized EEG-NIRS-Based Hybrid BCI and Monitoring in IEEE Transactions on biomedical engineering. 2017. Vol. 64. No. 6. P. 1199-1210. https://doi.org/ 10.1109/TBME.2016.2594127

17. Aleksandrowicz A., Leonhardt S. Wireless and Non-contact ECG Measurement System - the «Aachen SmartChair» in Acta Polytechnica. 2007. Vol. 47. No. 4-5. P. 68-71.

18. Jun S., Kochan O., Chunzhi W., Kochan R. Theoretical and experimental research of error of method of thermocouple with controlled profile of temperature field. In Measurement Science Review. 2015. Vol. 15. No. 6. P. 304-312. https://doi.org/10.1515/msr-2015-0041.

19. Wang J., Kochan O., Przystupa K., Su J. Information-measuring System to Study the Thermocouple with Controlled Temperature Field. In Measurement Science Review. 2019. Vol. 19. No. 4. P. 161-169. https://doi.org/10.2478/msr-2019-0022.

20. e-Health Sensor Platform V2.0 for Arduino and Raspberry Pi. URL: https://www.cookinghacks.com/documentation/tutorials/ehealth-biometric-sensor-platform-arduino-raspberry-pi-medical (last access: 21.09.19).

21. Orozco L. Synchronous Detectors Facilitate Precision, Low-Level Measurements. Analog Dialogue 48-11, November 2014. URL: https://www.analog.com/media/en/analog-dialogue/volume-48/number4/articles/synchronous-detectors-facilitate-precision.pdf (last access: 29.09.19).

22. He C.,Zhang L., Liu B., Xu Z., Zhang Z., A digital phase-sensitive detector for electrical impedance tomography. In 2008 World Automation Congress. WAC-2008. 28 Sept.-2 Oct. 2008. P. 1-4.

23. Zhengbing H., Kochan R., Kochan O., Jun S., Klym H. Method of integral nonlinearity testing and correction of multi-range ADC by direct measurement of output voltages of multi-resistors divider. In ACTA IMEKO. 2015. Vol. 4. No. 2. P. 80-84. https://doi.org/10.21014/acta_imeko.v4i2.230.

24. AN-1515 A comprehensive study of the howland current pump. Application Report SNOA474A - January 2008-Revised April 2013. P. 1-17.

25. Jian Q., Qun S., Xiaoliang W., Chong W., Linlin C. Design and analysis of a low cost wave generator based on direct digital synthesis. In Journal of Electrical and Computer Engineering. 2015. Vol. 17. P. 1-17. https://doi.org/10.1155/2015/367302

\title{
УДК 621.317
}

\section{УНІФІКАЦЯ АНАЛОГОВОЇ ЧАСТИНИ КАНАЛУ ОПРАЦЮВАННЯ БІОСИГНАЛІВ}

\section{Володимир Хома' ${ }^{1}$ Юрій Хома ${ }^{1}$; Орест Кочан ${ }^{1,2}$}

\author{
${ }^{1}$ Національний університет «Львівська політехніка», Львів, Україна \\ ${ }^{2}$ Школа комп 'ютерних наук, Університет Хубей, Ухань, Китай
}

Резюме. Потреба у вимірюванні та опрацюванні біосигналів виникає не лише у медичній діагностиці, але також багатьох нових застосуваннях, зокрема, у біометриці, афективній інформатиці 
людино-машинній взаємодії, иілодобовому клінічному моніторингу. Нові застосування підвищують вимоги до технічних і експлуатаціийних характеристик засобів відбору та перетворення біосигналів. Необхідно здійснювати відбір біосигналів поза стаціонарними умовами, забезпечити синхронне опрацювання різних видів біосигналів. У изьому контексті потрібно максимально уніфікувати апаратні засоби біоінформатичної системи, особливо ї̈ аналогову частину. У роботі розглянуто особливості формування $i$ відбору найпоширеніших біосигналів, проаналізовано джерела спотворень та описано типові вимірювальні перетворення на прикладах сигналу електрокардіограми й біоімпедансу. На підставі проведеного аналізу визначено завдання, щзодо уніфікації вимірювального каналу, які можуть бути рачіонально вирішені на основі використання можливостей компонентної бази сучасної мікроелектроніки та обчислювальної техніки. Показано можливість істотного спрощення вимірювального каналу вимірювання біопотенціалів, завдяки застосуванню багаторозрядних дельтасигма АЦП. Вимірювання біоімпедансу має свою специфіку через пасивну векторну природу цієї величини. Для иьього застосовують зовнішні джерела збудження, зазвичай, у вигляді джерела синусойдного струму частотою декілька десятків кілогери. Інформачію про складові біоімпеданса одержують за допомогою синхронного детектування. Обгрунтовано принции побудови та синтезовано структуру аналогової частини універсального вимірювального каналу, придатного для вимірювання як біосигналів, так $i$ біоімпеданса. Ï̈ основу складає багаторозрядний $i$ швидкодіючий АЦП, щзо відкриває можливість переведення частини вимірювальних перетворень до ичифрового вигляду, забезпечує стійкість до спотворень зумовлених артефактами та впливом завад.

Ключові слова: біосигнал, біоімпеданс, злиття сенсорів, вимірювальний канал, стійкість до спотворень.

https://doi.org/10.33108/visnyk_tntu2020.01.097

Отримано 19.03.2020 